\title{
Mineralogical and Geochemical Characterization of Gold Mining Tailings and Their Potential to Generate Acid Mine Drainage (Minas Gerais, Brazil)
}

\author{
Mariana Lemos ${ }^{1,2}$, Teresa Valente ${ }^{1, * \mathbb{D}}$, Paula Marinho Reis ${ }^{1,3}$, Rita Fonseca ${ }^{4}$, Itamar Delbem ${ }^{5}$, \\ Juliana Ventura $^{2}$ and Marcus Magalhães ${ }^{2}$
}

1 Institute of Earth Sciences, Pole of University of Minho, Campus de Gualtar, Universidade do Minho, 4710-057 Braga, Portugal; id8548@alunos.uminho.pt or mglemos@anglogoldashanti.com.br (M.L.); pmarinho@dct.uminho.pt (P.M.R.)

2 Anglogold Ashanti, Mining \& Technical, COO International, Nova Lima 34000-000, Brazil; jdventura@AngloGoldAshanti.com.br (J.V.); mfmagalhaes@AngloGoldAshanti.com.br (M.M.)

3 GEOBIOTEC, Departmento de Geociências, Campus Universitário de Santiago, Universidade de Aveiro, 3810-193 Aveiro, Portugal

4 Institute of Earth Sciences, Pole of University of Évora, University of Évora, 7000-345 Évora, Portugal; rfonseca@uevora.pt

5 Microscopy Center, Universidade Federal de Minas Gerais, Belo Horizonte 31270-013, Brazil; ssgerais@microscopia.ufmg.br

* Correspondence: teresav@dct.uminho.pt

check for updates

Citation: Lemos, M.; Valente, T.; Reis, P.M.; Fonseca, R.; Delbem, I.; Ventura, J.; Magalhães, M. Mineralogical and Geochemical Characterization of Gold Mining Tailings and Their Potential to Generate Acid Mine Drainage (Minas Gerais, Brazil). Minerals 2021, 11, 39.

https://doi.org/10.3390/min11010039

Received: 5 December 2020 Accepted: 24 December 2020 Published: 31 December 2020

Publisher's Note: MDPI stays neutral with regard to jurisdictional clai$\mathrm{ms}$ in published maps and institutional affiliations.

Copyright: $\odot 2020$ by the authors. Licensee MDPI, Basel, Switzerland. This article is an open access article distributed under the terms and conditions of the Creative Commons Attribution (CC BY) license (https:// creativecommons.org/licenses/by/ $4.0 /)$.
Abstract: For more than 30 years, sulfide gold ores were treated in metallurgic plants located in Nova Lima, Minas Gerais, Brazil, and accumulated in the Cocoruto tailings dam. Both flotation and leaching tailings from a deactivated circuit, as well as roasted and leaching tailings from an ongoing plant, were studied for their acid mine drainage potential and elements' mobility. Detailed characterization of both tailings types indicates the presence of fine-grain size material hosting substantial amounts of sulfides that exhibit distinct geochemical and mineralogical characteristics. The samples from the ongoing plant show high grades of Fe in the form of oxides, cyanide, and sulfates. Differently, samples from the old circuit shave higher average concentrations of $\mathrm{Al}(0.88 \%)$, $\mathrm{Ca}(2.4 \%), \mathrm{Mg}(0.96 \%)$, and $\mathrm{Mn}(0.17 \%)$, present as silicates and carbonates. These samples also show relics of preserved sulfides, such as pyrite and pyrrhotite. Concentrations of $\mathrm{Zn}, \mathrm{Cu}, \mathrm{Au}$, and As are higher in the tailings of the ongoing circuit, while $\mathrm{Cr}$ and $\mathrm{Hg}$ stand out in the tailings of the deactivated circuit. Although the obtained results show that the sulfide wastes do not tend to generate acid mine drainage, leaching tests indicate the possibility of mobilization of toxic elements, namely $\mathrm{As}$ and $\mathrm{Mn}$ in the old circuit, and $\mathrm{Sb}, \mathrm{As}, \mathrm{Fe}, \mathrm{Ni}$, and $\mathrm{Se}$ in the tailings of the plant that still works. This work highlights the need for proper management and control of tailing dams even in alkaline drainage environments such as the one of the Cocoruto dam. Furthermore, strong knowledge of the tailings' dynamics in terms of geochemistry and mineralogy would be pivotal to support long-term decisions on wastes management and disposal.

Keywords: geochemistry and environmental mineralogy; tailings; mobility of toxic elements; acid mine drainage; Minas Gerais-Brazil

\section{Introduction}

Mining of metals throughout the world produces high volumes of wastes represented by different types of materials [1]. Although highly variable as a function of the characteristics of the ore deposit and the beneficiation processes, as an example [2] estimated around 50,000 Mt of wastes, with 33\% of them in tailing dams. In plants for Au metallurgy, the ratio tailings/concentrate can achieve 200:1 [3]. In South Africa, one of the largest Au producing countries, [2] reported a production of $7.4 \times 10^{5} \mathrm{t}$ of tailings from 1997 to 2006 . 
These waste materials are discharged in tailing dams and/or ditches in conditions that could be dangerous to the environment. Even though the tailings treatment and control processes use alkaline products [4], the main sources of Au are often associated with sulfides, such as pyrite $\left(\mathrm{FeS}_{2}\right)$, arsenopyrite $(\mathrm{FeAsS})$, and pyrrhotite $\left(\mathrm{Fe}_{1-\mathrm{x}} \mathrm{S}\right)$. Deposition of these waste materials in subaerial storage facilities allows the oxidation of sulfides, which may promote the generation of acid mine drainage (AMD) [5-8] with the consequent mobilization of potentially toxic elements (PTE). Unregulated mining also deserves a special mention for its contribution to AMD pollution in regions with great influence of artisanal and small-scale mining operations $[9,10]$.

In order to assure safe closure conditions, it is important to evaluate the AMD potential in the long term and understand the factors that may control the mobility of PTE. Several parameters, in addition to the presence of sulfides, can contribute to generation of AMD and contamination of the surrounding environment [11-15]. Tailings can have a wide variety of chemical and mineralogical compositions and can suffer geochemical evolution controlled not only by the original ore paragenesis, but also depending on the mineral processing techniques and weathering conditions [15]. Supergenic evolution of the tailings results in a secondary paragenesis with high diversity of mineral phases, including soluble sulfates, oxides and iron oxyhydroxides, and arsenates, among others. These secondary minerals, occurring as efflorescences, crusts and other iron-rich precipitates, play important roles in the dynamics of the sulfide oxidation and in mobility of PTE in surface and groundwater [16-18]. Another important factor is the dimension of the tailing particles, as the relationship between size and exposure to weathering can directly influence the oxidation rate of sulfides $[7,19]$.

In general, AMD develops when the neutralization capacity of carbonate minerals or alkaline reagents used in the mineral processing plants (as lime) is depleted due to ongoing sulfide-mineral oxidation. In addition to carbonates, or when they are absent, silicate minerals can provide some level of acid buffering [19-22]. Nevertheless, major and trace elements, such as Se and As can be leached from the tailing dams, contributing to the contamination of water bodies, even if the global geochemical balance is neutral or even alkaline [8]. Furthermore, [23] presents a review of the geochemistry of these elements, emphasizing their sources and mobility in naturally contaminated rocks, namely due to desorption from iron-rich minerals.

Once the production of AMD starts, it is very complex to stop the process. In addition, the remediation techniques based on passive or active processes [24,25] are often inefficient or expensive as they require long-term application of the treatment strategies. Moreover, as mentioned by [26], these classical approaches demand an adequate control and disposal of the resulted PTE-enriched sludge.

Thus, for the management and control of the tailings, it is crucial to assess the AMD potential as well as the mobility of toxic elements such as As, Ni or Se. In general, a good understanding of the environmental behavior of the tailings involves a set of procedures, including acid base accounting and leaching tests (e.g., batch, column and/or in situ) $[3,14,15,27-35]$.

In this work, results of chemical, mineralogical and environmental evaluation of two different set of tailings from Au beneficiation are presented and discussed. The tailings represent different scenarios regarding mineralogy and geochemistry as well as mineral processing techniques and temporal evolution. Therefore, there are tailings from an old circuit (already deactivated) that are accumulated in an abandoned dam (Cocoruto dam) and tailings from an active plant, both located in Minas Gerais, Brazil. These two types represent distinctive beneficiation processes. The old circuit was a sulfide flotation plant and direct leaching. The ongoing circuit includes stages of calcination of sulfide concentrates and leaching.

The general objective is to compare the two types of tailings, using detailed geochemical and mineralogical characterization, namely for determining the AMD potential and the ability to mobilize PTE. This comparison intends to (i) understand the supergenic evolution 
of different tailings and (ii) support monitoring and identify possible opportunities for environmental improvements and management of both types of tailings.

\section{Location and Characterization of the Study Area}

The study area is in the Iron Quadrangle (QF), one of the most gold-producing regions in Brazil [36,37]. The gold world-class deposits are part of the Rio das Velhas Greenstone Belt, largely located in State of Minas Gerais (Figure 1a), with an estimated $4.5 \%$ of the world's ore reserves, almost half, about 936 tonnes [38-40]. The orebodies, hosted in Archaean rocks, are structurally associated and controlled by hydrothermal alteration. The mineralization is related to different typologies such as iron-banded formation, clastic and turbiditic metasedimentary rocks, and quartz veins enriched with sulfides, mainly pyrite, arsenopyrite, and pyrrhotite [38,40-42].

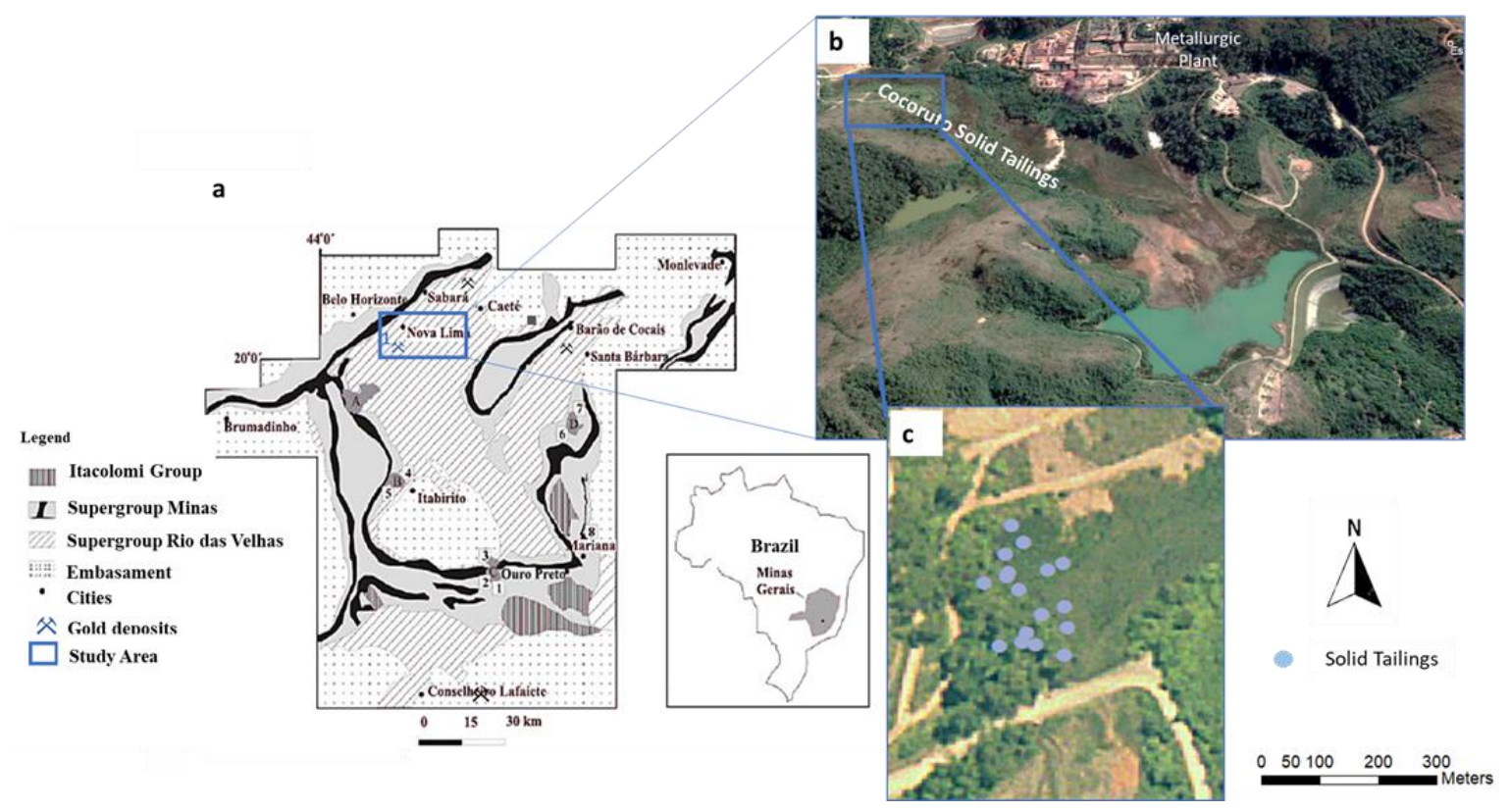

Figure 1. Location of the study area and Iron Quadrangle map (a) $[43,44]$; (b,c) Images of the Cocoruto Dam sampled area (SIRGAS2000-10-09-2019).

These sulfide $\mathrm{Au}$ ores have been treated for over 30 years in metallurgic plants located in Nova Lima, in the northern part of the QF, Minas Gerais, $25 \mathrm{~km}$ away from its capital, Belo Horizonte (Figure 1a). The region has a warm and temperate climate, according to the Cfa classification (humid subtropical climate). The average rainfall is around $1390 \mathrm{~mm}$ per year, with the month of August being the driest and the month of December having the highest rainfall, with an average of $302 \mathrm{~mm}$. The average temperature is $23.3^{\circ} \mathrm{C}$, with January the hottest month of the year while the lowest annual temperature is in June (average temperature of $17.6^{\circ} \mathrm{C}$ ) [45].

The circuits of the Nova Lima plant are and were fed by ores from the Raposos (Raposos circuits (Figure 2a)) and Cuiaba mines (Cuiaba circuit (Figure 2b) and ongoing roasted plant (Figure 2c)). The Raposos circuit (Figure 2a) is a plant that treated nonrefractory sulfide (pyrite, pyrrhotite and arsenopyrite) ore. The circuit reached $90 \%$ of $\mathrm{Au}$ recovery and was divided into grinding, gravity concentration, conventional leaching and CIP (carbon in leach), elution and electrorecovery. This part of the plant was deactivated in 1998 with the deactivation of the Raposos underground mining works, [46]. 


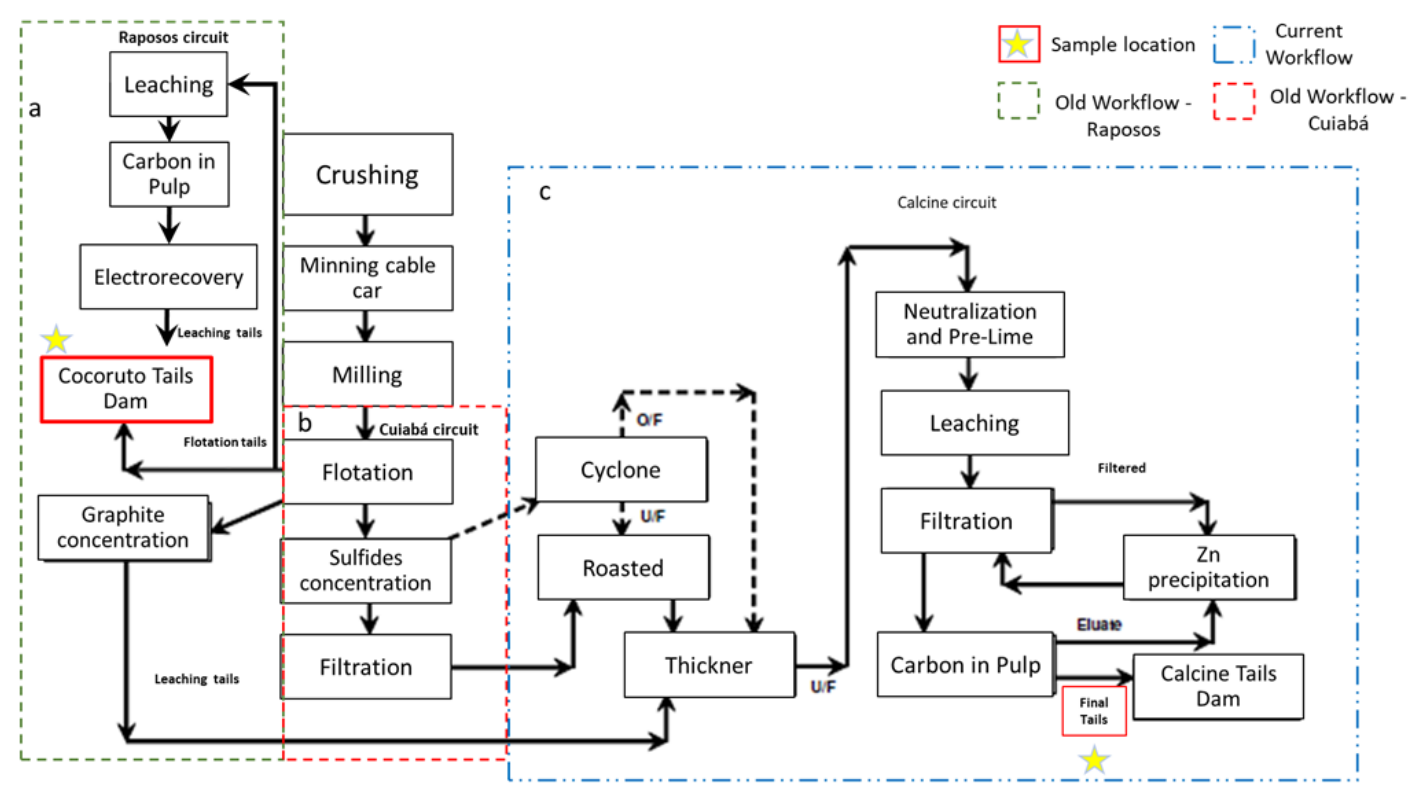

Figure 2. Old and ongoing workflow of Nova Lima's plant $(\mathbf{a}, \mathbf{b})$. Old circuit sources of Cocoruto Dam. (c) Ongoing workflow [46]. The yellow stars represent sampling points.

The Cuiaba circuit (Figure 2b) treats refractory ore (mainly Au enclosed in pyrite) with $92 \%$ of Au recovery and was divided into grinding, gravity concentration, sulfide flotation, roasting, neutralization, calcined leaching, CIP, elution and electrodeposition [46]. Currently at the Nova Lima plant, the material is treated from the roasting stage (Figure $2 \mathrm{c}$ ), as the previous steps are carried out directly at the plant located in the Cuiaba mine in Sabará, Minas Gerais. The tailings from the Raposos and the Cuiaba flotation circuits were deposited in a dam, already deactivated, named by Cocoruto (Figure 2a,b). The tailings from the ongoing circuit (roasting and leaching) are available in a dam known as calcined (Figure 2c).

Both structures are downstream type, monitored and declared safe according to the mining national agency [47]. In this study, the tailings samples representing the old circuits were collected directly at the Cocoruto dam, while the tailings from the ongoing circuit were collected directly at the calcined dam discharge. Therefore, the Nova Lima facility provides the opportunity to examine the potential environmental impact promoted by leaching and mobilization of PTE [48].

\section{Materials and Methods}

The sampling campaign was performed in the spring, a season (September 2019) in which weather conditions vary greatly. Typically, during this month it is common to alternate between dry and humid periods, with temperatures between $19^{\circ} \mathrm{C}$ and $25^{\circ} \mathrm{C}$ [45]. A total of 15 sites were selected in the Cocoruto dam (CoT samples) to represent the old circuit. Sampling, using percussion and auger methods, was performed at a maximum of $10 \mathrm{~m}$. Another set of fresh tailings samples (CaT samples) was collected over 28 days in September 2019 during the production stage, representing a total of 40 samples from the active plant (Figure 2c). All samples were immediately sealed and refrigerated until analysis. Additional material was transferred to polypropylene bags and frozen until analysis. Refrigerated and frozen samples were packaged and shipped to the chemical laboratory for analysis.

The chemical composition was analyzed by inductively coupled plasma mass spectrometry (ICP-MS, PerkinElmer SCIEX, Waltham, MA, USA—detection limit $0.001 \mathrm{mg} / \mathrm{kg}$ ) after acid digestion (nitric acid, hydrogen peroxide and hydrochloric acid) in accordance with Method 3050B published by the U.S. Environmental Protection Agency (USEPA) [49]. In addition, Au analyses were performed by atomic absorption spectroscopy (AAS, Varian, 
Palo Alto, CA, USA—detection limit $0.05 \mathrm{mg} / \mathrm{kg}$ ), using the fire assay method. All metal solutions were prepared from concentrated stock solutions (Sigma Aldrich). High-purity water produced with a Millipore Milli-Q system was used throughout the analytical process. Quality assurance and quality control (QC/QA) procedures included duplicates, blanks and standard reference materials for ICP-MS. Certified Reference Materials Si81 (Rocklabs) for solid tails were selected to represent a wide range of total elemental concentrations. Results of blanks were always below detection limits. Values for precision (expressed as RSD \%) were less than $5 \%$ for all elements.

The particle size distribution (PSD) was obtained by vibratory sieving between 212-38 $\mu \mathrm{m}$. In addition to the geochemical and PSD data, polished sections were prepared in composed samples for mineralogical characterization. The mineralogical study was carried out through optical microscopy and scanning electron microscopy (SEM-Field Electron and Ion Company-FEI; Hillsboro, OR, USA) at the UFMG, Belo Horizonte. The samples were analyzed in an FEI electronic microscope, Quanta 600 FEG, high vacuum mode, coupled to the automated analyzer software (MLA-mode GXMAP and SPL-DZ) and the EDS Espirit Bruker (20 Kve) microanalysis system.

The evaluation of acid mine drainage potential consisted of the comparison of the Modified Acid-Base Accounting (MABA) and Net Acid Generation Test (NAG-test) [50,51]. The acid base accounting (ABA) test is conducted to assess the static potential of generating acidic drainage from a material. It was conducted in accordance with the MEND guide [50] and aims to determine the balance between acid production and consumption from the mineral components of a given sample. Acid production and consumption were measured, respectively, using the parameters acidity potential (AP) and neutralization potential (NP). The NAG-test was carried out in accordance with the MEND guide [51], in which hydrogen peroxide was used to oxidize an aliquot $(2.5 \mathrm{~g})$ of comminuted sample $(<75 \mathrm{~mm})$. Final $\mathrm{pH}$ values (NAG-pH), and electrical conductivity were noted, and the liquor, filtered, was titrated with $\mathrm{NaOH}$ solution to defined $\mathrm{pH}$ values (4.5 and 7.0) in order to obtain indications on the global amount of non-neutralized acidity, per sample weight. The results of the NAG and MABA tests are compared with each other, allowing a refinement of the interpretation of the latter, and a more improved classification (according to both criteria) regarding the sample's AMD potential [50,51]. In addition, leaching test derived (SPLP) was carried out in accordance with the USEPA 1312 method [52].

\section{Results}

\subsection{Chemical Composition}

Table 1 and Figure 2 show the composition of the tailings. The elements were selected primarily based on the environmental relevance and inclusion in the Brazilian legal framework as well as potential economic interest. The samples from the ongoing process (CaT) comprise the following major elements, according to the decreasing order of their average concentration: $\mathrm{Fe}>\mathrm{Ca}>\mathrm{Al}>\mathrm{Mg}>\mathrm{K}>\mathrm{Mn}$, Na. The samples from the old Cocoruto dam (CoT) contain higher levels of Mn than CaT tailings: $\mathrm{Fe}>\mathrm{Ca}>\mathrm{Mg}>\mathrm{Al}>\mathrm{Mn}>\mathrm{K}, \mathrm{Na}$ (Table 1 and Figure 2). A relative depletion of the iron concentrations could be verified for the tailings deposited historically in the Cocoruto Dam. The elements Na and, especially K, on the other hand, had an enrichment of the order of $3 \times$ and $10 \times$, respectively (Table 1 and Figure 3).

The average concentrations of sulfur and cyanide in the ongoing process samples were also an order of magnitude higher than that of the CoT samples (Figure 3). Based only on the sulfur contents, this result could suggest that the CaT samples may have greater acid generation potential, compared to the samples from the Cocoruto Dam.

The trace elements with environmental interest [40] presented the following decreasing order of their average concentrations for CaT: $(\mathrm{As}>\mathrm{Zn}) 10 \mathrm{mg} / \mathrm{kg}>(\mathrm{Cu}>\mathrm{Ni}>\mathrm{Pb}>\mathrm{Co}$ ) $102 \mathrm{mg} / \mathrm{kg}>(\mathrm{Sb}, \mathrm{Cr}, \mathrm{Ba}, \mathrm{Cd}) 101 \mathrm{mg} / \mathrm{kg}$ and CoT (As) $103 \mathrm{mg} / \mathrm{kg}>$ (Zn) $102 \mathrm{mg} / \mathrm{kg}>$ $(\mathrm{Cr}>\mathrm{Cu}>\mathrm{Ni}>\mathrm{Pb}>\mathrm{Hg}) 101 \mathrm{mg} / \mathrm{kg}$. The As followed by $\mathrm{Zn}$ remained as the main trace elements of environmental interest in the samples of tailings collected both in mineral 
processing and in the Cocoruto Dam (Table 1 and Figure 4). The element Hg was not detected in the CaT samples, but it had an average content of $21 \mathrm{mg} / \mathrm{kg}$ in the samples from the Cocoruto Dam.

Table 1. Statistical summary of the major and trace elements. CoT—old circuit; CaT—ongoing circuit; $\mathrm{N}$-number of samples.

\begin{tabular}{|c|c|c|c|c|c|c|}
\hline Element & Source & $\mathbf{N}$ & Average & Standard Deviation & Minimum & Maximum \\
\hline \multirow{2}{*}{$\mathrm{Ag}(\mathrm{mg} / \mathrm{kg})$} & $\mathrm{CoT}$ & 30 & 0.5000 & 0.0000 & 0.5000 & 0.5000 \\
\hline & $\mathrm{CaT}$ & 40 & 3.260 & 0.5478 & 2.970 & 4.960 \\
\hline \multirow{2}{*}{$\mathrm{Al}(\%)$} & $\mathrm{CoT}$ & 30 & 0.8790 & 0.4150 & 0.5670 & 1.4820 \\
\hline & $\mathrm{CaT}$ & 40 & 0.622 & 0.0569 & 0.516 & 0.799 \\
\hline \multirow{2}{*}{$\mathrm{Sb}(\mathrm{mg} / \mathrm{kg})$} & $\mathrm{CoT}$ & 30 & 0.5000 & 0.0000 & 0.5000 & 0.5000 \\
\hline & $\mathrm{CaT}$ & 40 & 49.060 & 10.4800 & 29.600 & 70.300 \\
\hline \multirow{2}{*}{ As $(\mathrm{mg} / \mathrm{kg})$} & $\mathrm{CoT}$ & 30 & 1799 & 171.2 & 1610 & 2018 \\
\hline & $\mathrm{CaT}$ & 40 & 7905 & 878.0 & 3553 & 9275 \\
\hline \multirow{2}{*}{$\mathrm{Ba}(\mathrm{mg} / \mathrm{kg})$} & CoT & 30 & 17.1500 & 7.3800 & 12.0000 & 28.1000 \\
\hline & $\mathrm{CaT}$ & 40 & 23.427 & 2.4770 & 18.600 & 30.300 \\
\hline \multirow{2}{*}{$\mathrm{Cd}(\mathrm{mg} / \mathrm{kg})$} & $\mathrm{CoT}$ & 30 & 2.9325 & 0.0670 & 2.8700 & 3.0000 \\
\hline & $\mathrm{CaT}$ & 40 & 14.083 & 1.2010 & 11.000 & 17.000 \\
\hline \multirow{2}{*}{ Ca (\%) } & CoT & 30 & 2.3850 & 0.4850 & 1.9190 & 2.8720 \\
\hline & $\mathrm{CaT}$ & 40 & 1.672 & 0.1177 & 1.404 & 1.903 \\
\hline \multirow{2}{*}{$\mathrm{Pb}(\mathrm{mg} / \mathrm{kg})$} & CoT & 30 & 21.1000 & 4.4800 & 15.9000 & 26.7000 \\
\hline & $\mathrm{CaT}$ & 40 & 258.480 & 32.0600 & 215.000 & 343.000 \\
\hline \multirow{2}{*}{$\begin{array}{l}\text { Cyanide } \\
(\mathrm{mg} / \mathrm{kg})\end{array}$} & $\mathrm{CoT}$ & 30 & 2.9850 & 1.2920 & 1.6200 & 4.2600 \\
\hline & $\mathrm{CaT}$ & 40 & 51.890 & 21.1700 & 13.900 & 87.600 \\
\hline \multirow{2}{*}{ Co $(\mathrm{mg} / \mathrm{kg})$} & $\mathrm{CoT}$ & 30 & 4.0000 & 0.0000 & 4.0000 & 4.0000 \\
\hline & $\mathrm{CaT}$ & 40 & 116.330 & 11.7400 & 95.300 & 144.000 \\
\hline \multirow{2}{*}{$\mathrm{Cu}(\mathrm{mg} / \mathrm{kg})$} & $\mathrm{CoT}$ & 30 & 78.0500 & 15.4100 & 56.6000 & 93.0000 \\
\hline & $\mathrm{CaT}$ & 40 & 670.520 & 56.4700 & 583.000 & 824.000 \\
\hline \multirow{2}{*}{$\mathrm{Cr}(\mathrm{mg} / \mathrm{kg})$} & $\mathrm{CoT}$ & 30 & 85.2000 & 20.5000 & 59.0000 & 109.0000 \\
\hline & $\mathrm{CaT}$ & 40 & 35.020 & 8.4700 & 26.900 & 81.400 \\
\hline \multirow{2}{*}{$\mathrm{Fe}(\%)$} & $\mathrm{CoT}$ & 30 & 6.7600 & 0.5520 & 6.3970 & 7.5660 \\
\hline & $\mathrm{CaT}$ & 40 & 24.859 & 2.0270 & 21.557 & 28.974 \\
\hline \multirow{2}{*}{$\mathrm{P}(\%)$} & CoT & 30 & 0.0002 & 0.0000 & 0.0002 & 0.0002 \\
\hline & $\mathrm{CaT}$ & 40 & 0.047 & 0.0075 & 0.027 & 0.061 \\
\hline \multirow{2}{*}{$\operatorname{Mg}(\%)$} & $\mathrm{CoT}$ & 30 & 0.9570 & 0.2720 & 0.6340 & 1.2040 \\
\hline & $\mathrm{CaT}$ & 40 & 0.450 & 0.0424 & 0.317 & 0.520 \\
\hline \multirow{2}{*}{ Mn (\%) } & CoT & 30 & 0.1728 & 0.0307 & 0.1396 & 0.2119 \\
\hline & $\mathrm{CaT}$ & 40 & 0.079 & 0.0072 & 0.059 & 0.088 \\
\hline \multirow{2}{*}{$\mathrm{Hg}(\mathrm{mg} / \mathrm{kg})$} & CoT & 30 & 0.0688 & 0.0338 & 0.0250 & 0.1000 \\
\hline & $\mathrm{CaT}$ & 40 & 0.036 & 0.0274 & 0.025 & 0.160 \\
\hline \multirow{2}{*}{$\mathrm{Ni}(\mathrm{mg} / \mathrm{kg})$} & CoT & 30 & 72.2000 & 15.2200 & 52.9000 & 90.1000 \\
\hline & $\mathrm{CaT}$ & 40 & 392.630 & 51.7200 & 269.000 & 506.000 \\
\hline \multirow{2}{*}{$\mathrm{K}(\%)$} & $\mathrm{CoT}$ & 30 & 0.0411 & 0.0178 & 0.0226 & 0.0644 \\
\hline & $\mathrm{CaT}$ & 40 & 0.377 & 0.0310 & 0.326 & 0.471 \\
\hline \multirow{2}{*}{$\mathrm{Na}(\%)$} & $\mathrm{CoT}$ & 30 & 0.0091 & 0.0010 & 0.0086 & 0.0106 \\
\hline & $\mathrm{CaT}$ & 40 & 0.049 & 0.0050 & 0.041 & 0.062 \\
\hline \multirow{2}{*}{ Sulfates (\%) } & $\mathrm{CoT}$ & 30 & 0.2175 & 0.1763 & 0.0400 & 0.4400 \\
\hline & $\mathrm{CaT}$ & 40 & 1.505 & 0.1333 & 1.230 & 1.810 \\
\hline \multirow{2}{*}{$\mathrm{Zn}(\mathrm{mg} / \mathrm{kg})$} & $\mathrm{CoT}$ & 30 & 170.5 & 38.3 & 136 & 0.5000 \\
\hline & $\mathrm{CaT}$ & 40 & 2724 & 318.8 & 1941 & 1.430 \\
\hline $\mathrm{Au}(\mathrm{mo} / \mathrm{kg})$ & CoT & 30 & 1.055 & 0.6620 & 0.4800 & 2.010 \\
\hline Au (mg/kg) & $\mathrm{CaT}$ & 40 & 1.510 & 0.3731 & 0.3100 & 2.430 \\
\hline
\end{tabular}



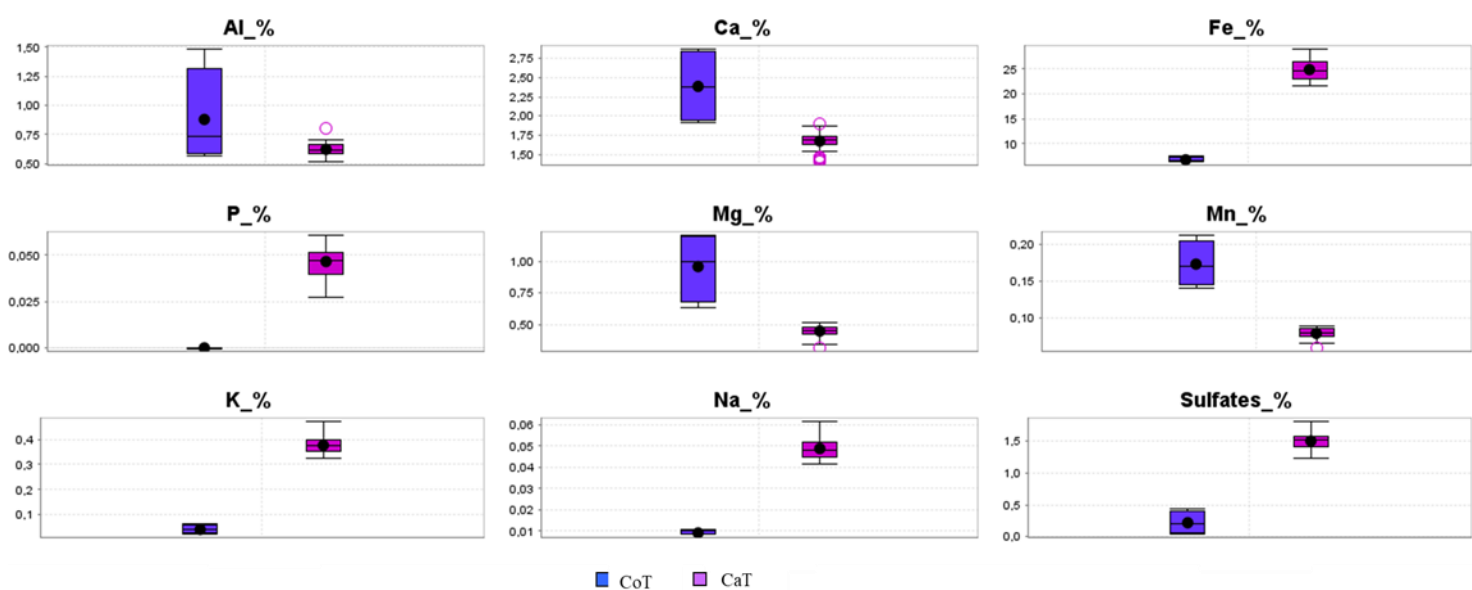

Figure 3. Basic statistics and comparison of major element (\%log) for the two sets of tailings samples.
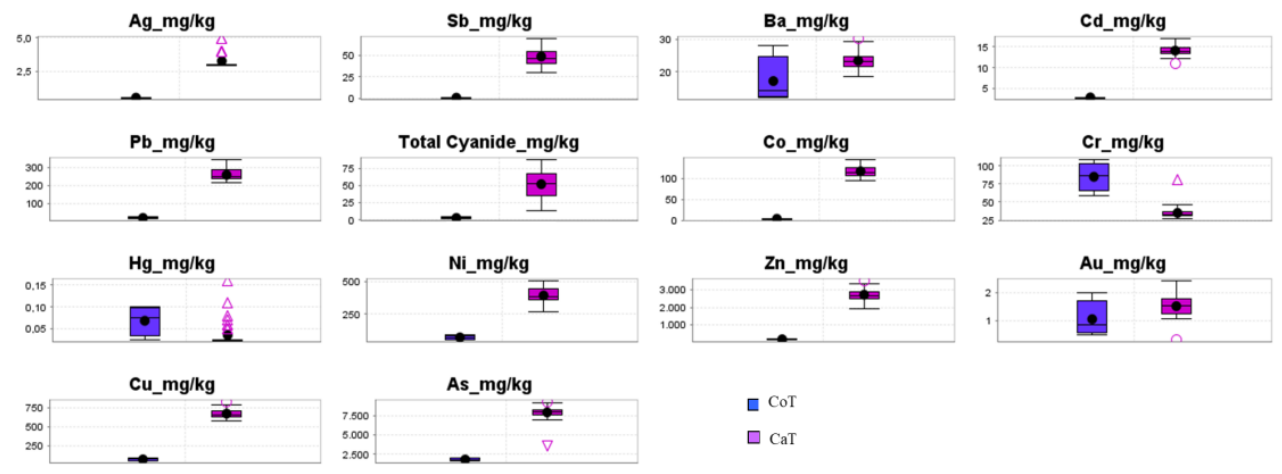

Figure 4. Basic statistics and comparison of trace element $(\mathrm{mg} / \mathrm{kg} \log )$ for the two sets of tailings samples.

\subsection{Size Particle Distribution}

In general, the grain size distribution (Figure 5) is similar to other dams that store tailings from $\mathrm{Au}$ exploitation $[7,8,27,53]$. The tailings presented $80 \%$ of their particles classified as silt-sized (Figure 5). The CoT samples are shown to have a thicker distribution than the ongoing process tailings (CaT). The difference can be explained by changes in the grinding process and different features of the ore sources and their variability [30]. In addition, the samples that represent CoT originate from older circuits, which have low grinding efficiency when compared to the ongoing one (CaT).

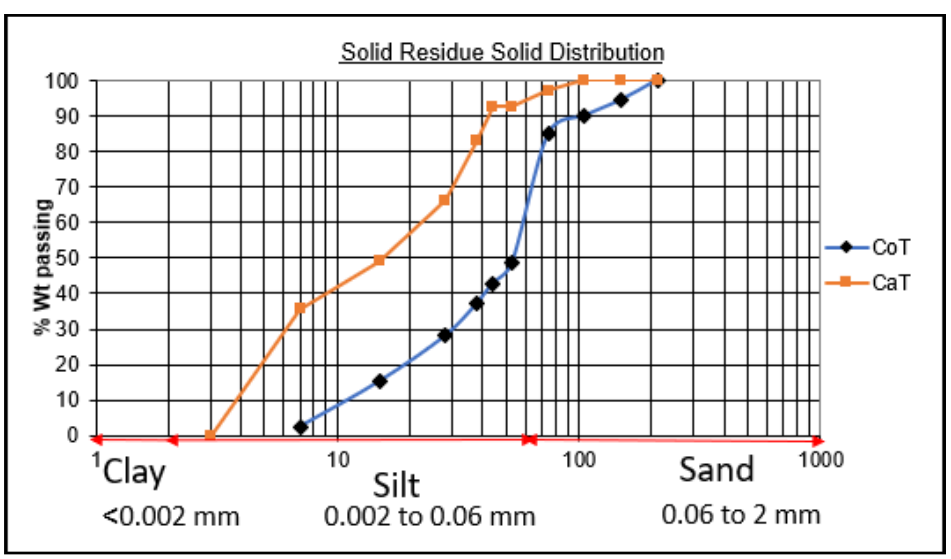

Figure 5. Size distribution (Krumbein phi scale) of solid tailings. 


\subsection{Mineralogy}

Table 2 shows the mineralogical composition of both tailings. The samples from the Cocoruto dam (old circuit) consist mainly of quartz, carbonates, iron oxides and phyllosilicates such as muscovite and chlorite (Figure 6). This is in accordance with higher $\mathrm{Al}, \mathrm{Ca}$ and $\mathrm{Mg}$ concentrations. Sulfides are present, but they look well-preserved, mainly in the form of iron sulfides with sphalerite, covellite and arsenopyrite subordinated.

Table 2. Mineralogical Composition of CaT and CoT.

\begin{tabular}{|c|c|c|c|}
\hline Minerals & Chemical Formula & $\mathrm{CaT}(\mathrm{Wt} \%)$ & $\operatorname{CoT}(\mathrm{Wt} \%)$ \\
\hline Quartz & $\mathrm{SiO}_{2}$ & 15.6 & 55.8 \\
\hline \multicolumn{4}{|l|}{ Feldspar Group } \\
\hline Albite & $\mathrm{NaAlSi}_{3} \mathrm{O}_{8}$ & 1.50 & 0.370 \\
\hline Anorthite & $\mathrm{CaAl}_{2} \mathrm{Si}_{2} \mathrm{O}_{8}$ & 0.053 & 0.01 \\
\hline K feldspar & $\mathrm{KAlSi}_{3} \mathrm{O}_{8}$ & & 0.390 \\
\hline \multicolumn{4}{|l|}{ Phyllosilicates } \\
\hline Biotite & $\mathrm{KMg}_{2.5} \mathrm{Fe}_{0.5} \mathrm{AlSi}_{3} \mathrm{O}_{10}(\mathrm{OH})_{1.75} \mathrm{~F}_{0.25}$ & 1.00 & 0.16 \\
\hline Smectite & $(\mathrm{Si}, \mathrm{Al})(\mathrm{Mg}, \mathrm{Fe}) \mathrm{O}(\mathrm{OH}) \mathrm{NaH}_{2} \mathrm{O}$ & 1.80 & 0.13 \\
\hline Muscovite Group & $\mathrm{KAl}_{3} \mathrm{Si}_{3} \mathrm{O}_{10}(\mathrm{OH})_{1.9} \mathrm{~F}_{0.1}$ & 11.0 & 5.56 \\
\hline Chlorite & $(\mathrm{Mg}, \mathrm{Fe})_{3}(\mathrm{Si}, \mathrm{Al})_{4} \mathrm{O}_{10}(\mathrm{OH})_{2} \cdot(\mathrm{Mg}, \mathrm{Fe})_{3}(\mathrm{OH})_{6}$ & 3.30 & 6.12 \\
\hline \multicolumn{4}{|l|}{ Oxides } \\
\hline $\begin{array}{c}\text { Iron } \\
\text { Oxides/Hydroxides }\end{array}$ & $\mathrm{Fe}_{2} \mathrm{O}_{3} / \mathrm{FeOOH}$ & 56.8 & 8.86 \\
\hline Rutile/Anathase & $\mathrm{TiO}_{2}$ & 0.599 & 0.49 \\
\hline \multicolumn{4}{|l|}{ Carbonates } \\
\hline Ankerite & $\mathrm{Ca}(\mathrm{Fe}, \mathrm{Mg}, \mathrm{Mn})\left(\mathrm{CO}_{3}\right)$ & 1.00 & 11.2 \\
\hline Siderite & $\mathrm{FeCO}_{3}$ & - & 7.25 \\
\hline Calcite & $\mathrm{CaCO}_{3}$ & 0.200 & 2.25 \\
\hline \multicolumn{4}{|l|}{ Sulfates } \\
\hline Gypsum & $\mathrm{CaSO}_{4} 2 \mathrm{H}_{2} \mathrm{O}$ & 7.00 & 0.030 \\
\hline \multicolumn{4}{|l|}{ Sulfides } \\
\hline Pyrite & $\mathrm{FeS}_{2}$ & 0.002 & 0.500 \\
\hline Pyrrhotite & $\mathrm{Fe}_{(1-\mathrm{x})} \mathrm{S}$ & 0.004 & 0.790 \\
\hline Arsenopyrite & FeAsS & 0.056 & 0.240 \\
\hline Gesdorffite & NiAsS & 0.010 & - \\
\hline Covellite & CuS & 0.100 & 0.070 \\
\hline Sphalerite & $\mathrm{ZnS}$ & - & 0.010 \\
\hline \multicolumn{4}{|l|}{ Gold Minerals } \\
\hline Native Gold & $\mathrm{Au}>80 \%, \mathrm{Ag}, \mathrm{Cu}, \mathrm{Hg}$ & $(526)$ & $(364)$ \\
\hline Electrum & $\mathrm{Au}=80 \%, \mathrm{Ag}=20 \%$ & $(42)$ & $(10)$ \\
\hline
\end{tabular}

The samples from the ongoing process (CaT) are characterized by high concentrations of iron oxides, in addition to sulfates and silicates (mainly quartz). The high concentration of oxides justifies higher Fe contents than the samples of Cocoruto. Sulfides are reliquaries, associated with oxidized phases, and are rare. In Figure $6 \mathrm{~b}$, is identified, in false images, the presence of $\mathrm{As}, \mathrm{Cu}, \mathrm{Ni}$, and $\mathrm{Zn}$ with oxidized phases, in addition to $\mathrm{Fe}$. In both types of samples there are still fine Au grains. These particles are associated with iron oxides in the CaT and with sulfides in CoT samples. (Figure 6a-d). The optical microscopy images (Figure 6e-f) support these observations, showing the dominant hematite in CaT samples and the presence of $\mathrm{Au}$ in association with pyrite in CoT samples, respectively.

\subsection{AMD Potential}

The results of the MABA tests are presented graphically in Figure 7. Calcined samples collected in mineral processing showed relatively small variability in acidity (AP) and neutralization potentials (NP): In the first case, it ranged between 1.5 and $2.5 \mathrm{~kg} / \mathrm{CaCO}_{3}$ $\mathrm{t}$ and, in the second, it varied between 8.3 and $15.5 \mathrm{~kg} / \mathrm{CaCO}_{3} \mathrm{t}$. All these samples were 
classified as potentially non-acid-forming (PNA) by the MABA assay criterion, as they presented NP/AP ratio (NPR) $>2$. The average NPR value for CaT corresponded to $6.1 \mathrm{~kg} / \mathrm{CaCO}_{3} \mathrm{t}$.
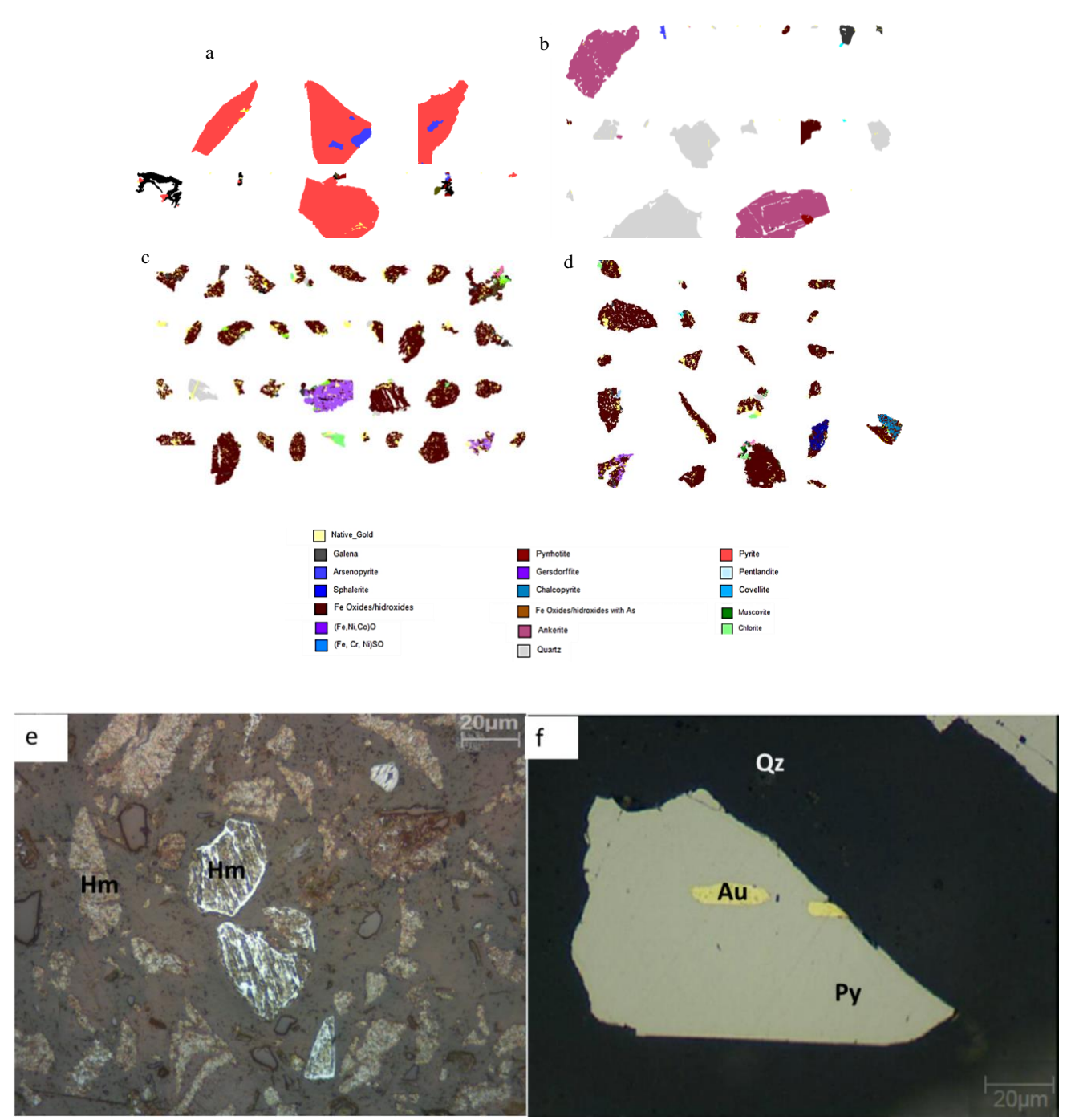

Figure 6. False Images (a) sulfides associated with iron oxide and Au particles-CoT, (b) quartz, carbonates and Fe oxides particles-CoT, (c,d) Fe oxides associated with $\mathrm{Au}$, silicates and Fe oxides with $\mathrm{As}, \mathrm{Ni}, \mathrm{Co}, \mathrm{Al}, \mathrm{Zn}, \mathrm{Pb}-\mathrm{CaT}$ samples. Photomicrographs taken under reflected light and uncrossed nico (e) hematite (Ht) from CaT samples and (f) Au associated with pyrite (Py)—CoT samples.

The tailings samples collected at the Cocoruto Dam showed relevant dispersion of acidity and neutralization potentials, in accordance with the mineralogical features. The $\mathrm{AP}$ values oscillated mainly in the range of $5-150 \mathrm{~kg} / \mathrm{CaCO}_{3} \mathrm{t}$. NP values between 44 to $123 \mathrm{~kg} / \mathrm{CaCO}_{3} \mathrm{t}$. This dispersion resulted in the following relative potentials for the generation of acid drainage, according to the MABA test criteria: Nonacid-forming samples $(\mathrm{NPR}>2$ ) represent $45 \%$, samples in the uncertainty zone (NPR 1 to 2 ) are $50 \%$, and samples acid-forming $(\mathrm{NPR}<1)$ are $5 \%$. Vertically, the samples in the uncertainty zone corresponded mainly to depths of 4.0 to $5.5 \mathrm{~m}$ and 8.0 to $11.5 \mathrm{~m}$. The non-acid-forming samples occurred mainly between 0.0 and $1.5 \mathrm{~m}$ and from 6.0 to $7.5 \mathrm{~m}$ in depth (Figure $7 \mathrm{~b}$ ).

The NAG test (net acid generation) was another method used in order to compare with the results obtained by MABA, mainly because of the $S$ grades. Figure 8 presents the graph NAGpH versus NPR, allowing to correlate the results of the MABA and NAG-tests, and to better refine the classification of acid generation potential of the samples under 
analysis. The results of the NAG test showed a $\mathrm{pH}$ value well above the limit of 4.5, indicating all samples as non-acid-forming, regardless of the result of the NPR. The $\mathrm{pH}$ fluctuated from 7.4 to 8.5 for samples from the Cocoruto Dam, and from 8.1 to 9.5 for process samples. These results indicate less potential for liquid acidity than previously indicated, only by the NPR (MABA) criterion. The summary of the assessment of the potential for acidity generation, based on the MABA and NAG, therefore, demonstrates that all process samples resulted in potentially non-acid forming (NAF). Only $45 \%$ of the samples collected at the Cocoruto Dam resulted in potentially non-acid forming, using the MABA criterion. However, this number was $100 \%$ using the NAG criterion.

a

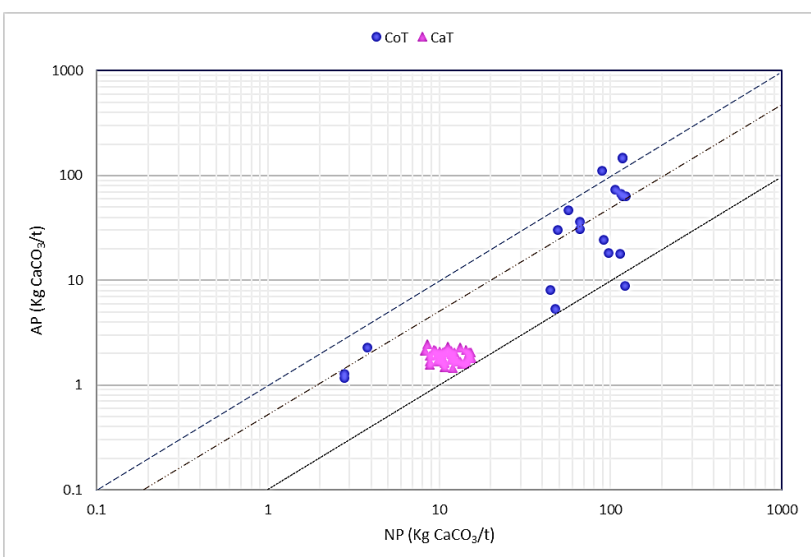

b

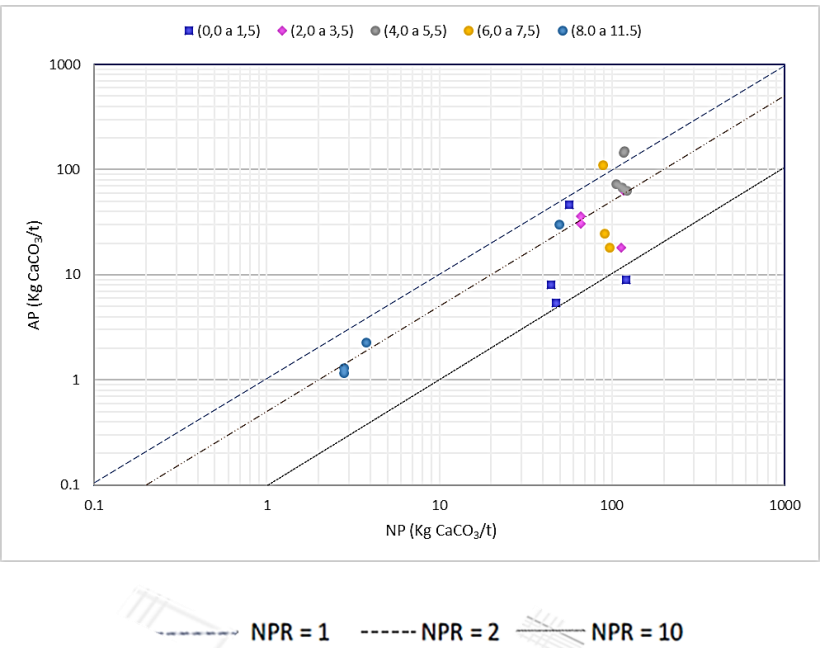

Figure 7. Results of Modified Acid-Base Accounting (MABA) tests (a) global and (b) for CoT, by sampling depth.

\subsection{SPLP Leaching}

In addition to the tests already presented, the SPLP leaching test (USEPA 1312 method) was carried out in order to assess the potential for leaching toxic elements. Data from leaching tests can be used as indicators of potentially contaminating substances, even though the test conditions are very limited in view of the environmental geochemical conditions. A basic criterion used to assess the magnitude of the potential impact is the comparison with benchmarks in the context of the legal framework. The Brazilian law, through CONAMA Resolution 396/2008, was used as reference for the permitted limits of the following elements: $\mathrm{Al}, \mathrm{Sb}, \mathrm{As}, \mathrm{Ba}, \mathrm{Be}, \mathrm{Cd}, \mathrm{Pb}, \mathrm{Co}, \mathrm{Cu}, \mathrm{Cr}, \mathrm{Fe}, \mathrm{Mn}, \mathrm{Hg}, \mathrm{Ni}, \mathrm{Ag}$ and $\mathrm{Zn}$. Since there is no definition for the predominant industrial use, recreation was defined as the predominant use. 


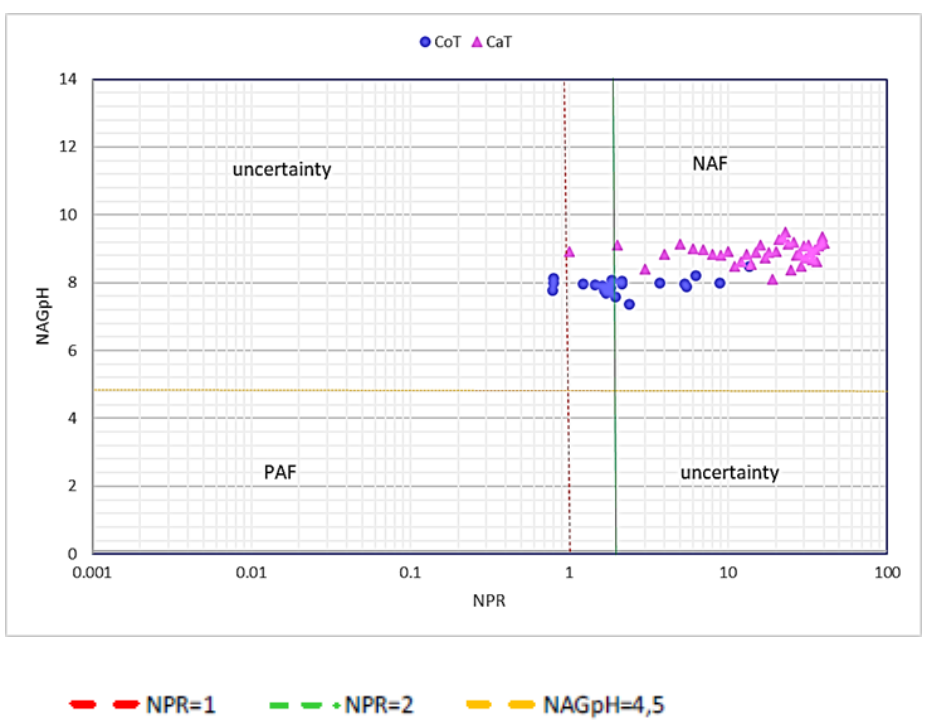

Figure 8. Relationship between the results of the MABA and Net Acid Generation (NAG) pH tests (NAF: region of non-acid-forming samples; PAF: region of potentially acid-forming samples).

The elements $\mathrm{Cd}, \mathrm{Pb}, \mathrm{Hg}$, and $\mathrm{Zn}$ were not detected in the leaching extracts (Table 3 and Figure 9), with two exceptions: $\mathrm{Pb}$ equal to $0.02 \mathrm{mg} / \mathrm{L}$, and $\mathrm{Zn}$ equal to $0.1 \mathrm{mg} / \mathrm{L}$ in a sample from the Cocoruto Dam. In the extracts of this dam, only the elements As and Mn showed concentrations above the respective legal reference (VMP) (i.e., $0.05 \mathrm{mg}$ As/L, and $0.1 \mathrm{mg} \mathrm{Mn} / \mathrm{L}$ ). The average concentrations were around an order of magnitude higher than the VMP, in these cases (Figure 9).

Table 3. VMP—maximum allowed values From Brazilian Law_CONAMA [54].

\begin{tabular}{|c|c|c|}
\hline Samples & Not Detected Elements & $\begin{array}{c}\text { Parameters with Values AboveVMP } \\
\text { Conama } 2005 \text { Reference }\end{array}$ \\
\hline CoT & $\mathrm{Cd}, \mathrm{Hg}, \mathrm{Pb}, \mathrm{Zn}$ & $\begin{array}{l}\text { As (VMP } 0.05 \mathrm{mg} / \mathrm{L}) \\
\mathrm{Mn}(\mathrm{VMP} 0.1 \mathrm{mg} / \mathrm{L})\end{array}$ \\
\hline CaT & $\mathrm{Cd}, \mathrm{Hg}, \mathrm{Pb}, \mathrm{Zn}$ & $\begin{array}{c}\text { As (VMP } 0.05 \mathrm{mg} / \mathrm{L}) \\
\text { Fe (VMP } 0.3 \mathrm{mg} / \mathrm{L}) \\
\text { Ni (VMP } 0.1 \mathrm{mg} / \mathrm{L}) \\
\text { Se (VMP } 0.01 \mathrm{mg} / \mathrm{L})\end{array}$ \\
\hline
\end{tabular}
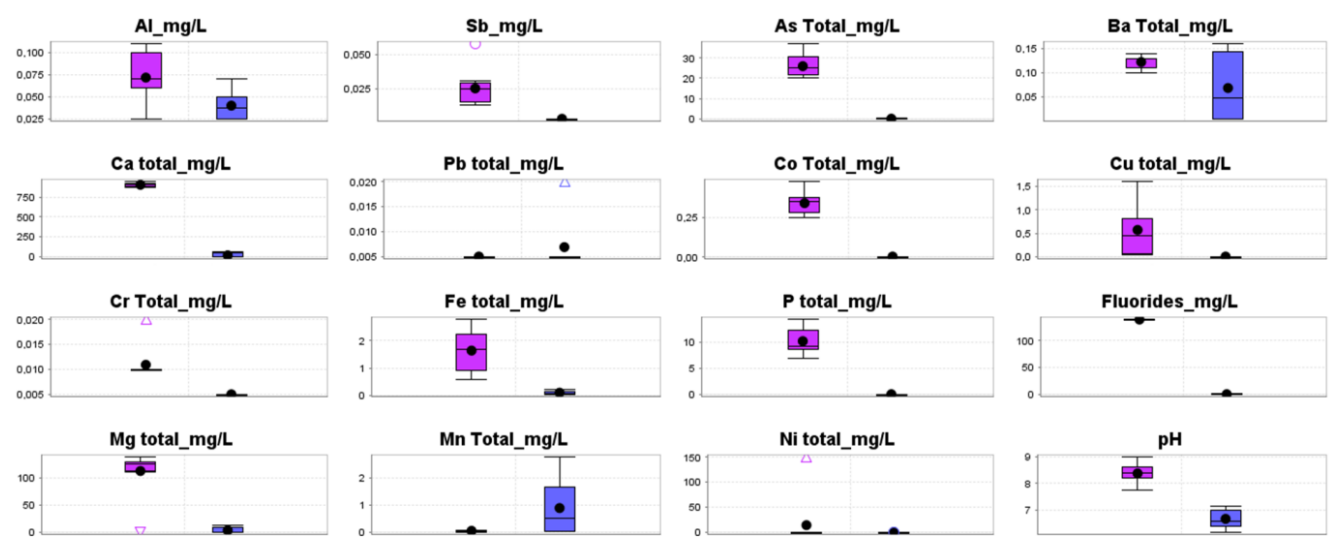

Figure 9. Comparison of the average levels of metals, metalloids, fluorides and $\mathrm{pH}$ in SPLP leaching extracts. VMP $\mathrm{Al}=0.2$ $\mathrm{mg} / \mathrm{L} ; \mathrm{VMP} \mathrm{Sb}=\mathrm{NA} ; \mathrm{VMP}$ As $=0.05 \mathrm{mg} / \mathrm{L} ; \mathrm{VMP} \mathrm{Ba}=1.0 \mathrm{mg} / \mathrm{L} ; \mathrm{VMP} \mathrm{Ca}=\mathrm{NA} ; \mathrm{VMP} \mathrm{Pb}=0.05 \mathrm{mg} / \mathrm{L} ; \mathrm{VMP} \mathrm{Co}=\mathrm{NA}$; $\mathrm{VMP} \mathrm{Cu}=1.0 \mathrm{mg} / \mathrm{L} ; \mathrm{VMP} \mathrm{Cr}=0.05 \mathrm{mg} / \mathrm{L} ; \mathrm{VMP} \mathrm{Fe}=0.3 \mathrm{mg} / \mathrm{L} ; \mathrm{VMP} \mathrm{P}=\mathrm{NA} ; \mathrm{VMP}$ Fluorides = NA; VMP Mg = NA; VMP $\mathrm{Mn}=0.1 \mathrm{mg} / \mathrm{L} ; \mathrm{VMP} \mathrm{Ni}=0.1 \mathrm{mg} / \mathrm{L} . \mathrm{NA}-\mathrm{Not}$ applied for recreation use. 
On the other hand, in the calcined ongoing process the elements $\mathrm{As}, \mathrm{Fe}, \mathrm{Ni}$, and $\mathrm{Se}$ showed values above the CONAMA references, in at least one of the leaching extracts.

\section{Discussion}

The differences in particle distribution could contribute to differentiate the two types of tailings regarding the speed and magnitude of AMD. It is known that the rate of oxidation of sulfides is directly related to the size of the particles and the availability of the surface for reaction $[20,55]$. The mineralogical characteristics confirmed the distinction between tailings that were subjected to different processes, in accordance with the geochemical signatures (Figure 1). Such geochemical and mineralogical diversity could result in different potentials for mobilizing pollutants in AMD. For example, the higher amounts of sulfides in the Cocoruto tailings (old circuit) could suggest higher potential for AMD generation. However, Figure 6 suggests that inhibition of the oxidative dissolution processes occurs, since the sulfide grains are preserved. Moreover, AMD generation could be controlled by the presence of carbonates due to the ore paragenesis and metallurgical ore treatment [7]. Neutralization conditions also occur in CaT samples due to the addition of lime.

The chemical and mineralogical study highlights the occurrence of high grades of $\mathrm{Au}$ in these two sets of tailings. In CoT samples, the concentration reaches $1.0 \mathrm{mg} / \mathrm{kg}$ with $\mathrm{Au}$ crystals associated with sulfides and rock minerals such as carbonates and silicates (Figure $6 \mathrm{a}, \mathrm{b})$. In the ongoing process, in CaT samples, the concentration reaches $1.70 \mathrm{mg} / \mathrm{kg}$, with grains enclosed in iron oxides (Figure $6 \mathrm{c}$ ). Both Au features portray limitations and problems in the beneficiation old and ongoing processes. However, this inefficiency of the mineral separation processes may represent an opportunity for creating profit through valorization of the mine wastes. The reuse of tailings is now an important research line, as discussed in [53,56-60]. Especially in view of the scenario experienced in Brazil after the mediatized disasters of the Mariana (2015) and Brumadinho (2019) dams [61-64], it is crucial to find sustainable solutions for the closure stage. Therefore, in the present cases, the obtained results suggest the possibility of transforming an environmental liability into an economic outcome.

The tests for prediction of AMD indicate that minimum $\mathrm{pH}$ is around 8 , reaching a maximum of 9.6, reflecting the alkaline products used for extraction of Au with cyanide solutions. However, the levels of S present in the forms of sulfate and sulfide, thin PSD, and the presence of toxic leachable elements above permitted limits do not rule out the generation of AMD in practice if the tailings are stored improperly. These results, in addition to geochemical and mineralogical features, imply that the samples from the Cocoruto Dam are not potentially acid-forming under the conditions in which they are disposed. The net potential for acidity generation is low. However, in the case of removal of these materials, they must be disposed properly, without long-term exposure (months/years).

Under $\mathrm{pH}$ conditions close to neutrality, a series of trace elements can remain solubilized [8], as verified for As, Fe, Ni, Mn and Se. This behavior was also observed by [23], specifically for As and Se leached out in underground rock excavation works. The $\mathrm{Al}$ for the sample of the CoT tailings was an exception. Thus, the generation of effluents with metals or metalloids does not require long periods of exposure of sulfide minerals [7]. The As stood out in SPLP leaching test, with an average concentration $(26 \mathrm{mg}$ As/L), $3 \times$ of magnitude above the permitted limits by the Brazilian law (VMP). This could be explained by the presence of arsenopyrite in CoT samples and iron oxide in CaT. For the other parameters mentioned, the averages values cofound were up to an order of magnitude higher than the corresponding VMP.

\section{Conclusions}

An integrated characterization of tailings from different mineral beneficiation processes was performed to evaluate the environmental risk of mobilizing pollutants from the mine drainage. 
The tailings presented $80 \%$ of their particles classified as silt-sized. Sulfides are present in the samples from the historic Cocoruto dam, but they appear well-preserved. The tailings consist mainly of quartz $(55.8 \%)$, carbonates $(20.7 \%)$, iron oxides $(8.86 \%)$, muscovite $(5.56 \%)$ and chlorite $(6.12 \%)$. Therefore, the potential acidity associated with sulfides could be neutralized by the dissolution of carbonates, such as calcite and silicates such as chlorite, besides the reagents used during the process. This fact contributes to make it a less dangerous waste when compared to the current one (CaT).

The tailings from the ongoing process $(\mathrm{CaT})$ are characterized by high contents of iron oxides $(56.8 \%)$, gypsum $(7 \%)$ and silicates (mainly quartz-15.6\%). In both types of tailings, the chemical composition allowed to identify elements with environmental relevance by their toxicity, namely $\mathrm{Mn}$ in the old tailings and $\mathrm{As}, \mathrm{Fe}$, and $\mathrm{Ni}$ in the more recent tailings. In addition to these elements of environmental concern, it should be noted the interesting values of $\mathrm{Au}$ (up to $2.4 \mathrm{mg} / \mathrm{kg}$ in the recent tailings), suggesting a potential for reuse during closures of dam facilities or tailings mass-rearrangement needs.

The geochemical tests, MABA and NAG, indicate that these tailings are not potentially acid-forming, under the conditions in which they are disposed. The net potential for acidity generation is low. However, the results of the SPLP leaching tests indicated a leaching potential for As and $\mathrm{Mn}$ in the Cocoruto Dam. Samples that are subject to calcination indicate leaching potential for other elements, namely $\mathrm{Sb}, \mathrm{As}, \mathrm{Fe}, \mathrm{Ni}$, and $\mathrm{Se}$. It is of note that As concentrations in these samples were two orders of magnitude higher than the ones found in samples from Cocoruto Dam. Moreover, the concentrations of S present in the forms of sulfate and sulfide, together with thin PSD and the presence of leachable PTE above permitted limits by the Brazilian law are important issues of concern. In the case of tailings mobilization or inappropriate storage, the generation of AMD and contamination by PTE is likely to occur.

Author Contributions: Conceptualization, M.L., T.V., P.M.R. and R.F.; Data curation, M.L., T.V., I.D., J.V. and M.M.; Funding acquisition, M.L., T.V. and J.V.; Investigation, M.L., T.V., P.M.R., R.F., I.D., J.V. and M.M.; Resources, T.V. and J.V.; Supervision, T.V.; Visualization, M.L. and T.V.; Writing_-original draft, M.L., T.V., P.M.R. and R.F. All authors have read and agreed to the published version of the manuscript.

Funding: This work was funded by FCT—Fundação para a Ciência e a Tecnologia through projects UIDB/04683/2020 e UIDP/04683/2020 and Nano-MINENV 029259 (PTDC/CTA-AMB/29259/2017, and by AngloGold Ashanti Brazil.

Institutional Review Board Statement: Not applicable.

Informed Consent Statement: Not applicable.

Data Availability Statement: Not applicable.

Acknowledgments: We thank our colleagues from ICT, microscopy center from Universidade Federal de Minas Gerais (CM-UFMG), and AngloGold Ashanti who provided insight and expertise that greatly assisted the research. The authors are grateful to the two anonymous reviewers and to the editor Dr Carlito Tabelin for their valuable contributions to improving the manuscript.

Conflicts of Interest: Authors declare no conflict of interest.

\section{References}

1. Mohapatra, D.; Kirpalani, D. Process effluents and mine tailings: Sources, effects and management and role of nanotechnology. Nanotechnol. Environ. Eng. 2017, 2, 1-12. [CrossRef]

2. Blight, G. Mine waste: A brief overview of origins, quantities, and methods of storage. In Waste: A Handbook for Management, 2nd ed.; Letcher, T., Vallero, D., Eds.; Academic Press: Cambridge, MA, USA, 2011; pp. 77-88.

3. Lottermoser, B. Mine Wastes: Characterization, Treatment and Environmental Impacts; Springer: New York, NY, USA, $2012 ;$ pp. 1-400. ISBN 978-3-662-05133-7.

4. Park, I.; Tabelin, C.B.; Jeon, S.; Li, X.; Seno, K.; Ito, M.; Hiroyoshi, N. A review of recent strategies for acid mine drainage prevention and mine tailings recycling. Chemosphere 2019, 219, 588-606. [CrossRef] [PubMed] 
5. $\quad$ Blowes, D.W.; Jambor, J.L.; Hanton-Fong, C.J.; Lortie, L.; Gould, W.D. Geochemical, mineralogical and microbiological characterization of a sulphide-bearing carbonate-rich gold mine tailings impoundment, Joutel, Quebec. Appl. Geochem. 1998, 13, 687-705. [CrossRef]

6. Johnson, D.B. Chemical and microbiological characteristics of mineral spoils and drainage waters at abandoned coal and metal mines. Water Air Soil Pollut. 2003, 3, 47-66. [CrossRef]

7. Lindsay, M.B.; Condon, P.D.; Jambor, J.L.; Lear, K.G.; Blowes, D.W.; Ptacek, C.J. Mineralogical, geochemical, and microbial investigation of a sulfide-rich tailings deposit characterized by neutral drainage. J. App. Geochem. 2009, 24, 2212-2221. [CrossRef]

8. Bissacot, L.; Ciminelli, V.; Logsdon, M. Arsenic Mobility under a Neutral Mine Drainage Environment in a Gold-Mine Tailings Dam-In Agreeing on solutions for more sustainable mine water management. In Proceedings of the 10th International Conference on Acid Rock Drainage \& IMWA Annual Conference (ICARD \& IMWA-2005), Santiago, Chile, 21-24 April 2005; pp. 170-174.

9. Opiso, E.; Aseneiro, J.; Banda, M.; Tabelin, C.B. Solid-phase partitioning of mercury in artisanal gold mine tailings from selected key areas in Mindanao, Philippines, and its implications for mercury detoxification. Waste Manag. Res. 2018, 36, 269-276. [CrossRef] [PubMed]

10. Tabelin, C.B.; Silwamba, M.; Paglinawan, F.C.; Mondejar, A.J.S.; Duc, H.G.; Resabal, V.J.; Opiso, E.M.; Igarashi, T.; Tomiyama, S.; Ito, M.; et al. Solid-phase partitioning and release-retention mechanisms of copper, lead, zinc and arsenic in soils impacted by artisanal and small-scale gold mining (ASGM) activities. Chemosphere 2020, 260, 127574. [CrossRef]

11. Nordstrom, K. Mine Waters: Acidic to Circumneutral. Elements 2011, 7, 393-398. [CrossRef]

12. Nordstrom, D.K. Hydrogeochemical processes governing the origin, transport and fate of major and trace elements from mine wastes and mineralized rock to surface waters. Appl. Geochem. 2011, 26, 1777-1791. [CrossRef]

13. Smuda, J.; Dold, B.; Spangenberg, J.E.; Friese, K.; Kobek, M.R.; Bustos, C.A.; Pfeifer, H.R. Element cycling during the transition from alkaline to acidic environment in an active porphyry copper tailings impoundment, Chuquicamata, Chile. J. Geochem. Explor. 2014, 140, 23-40. [CrossRef]

14. Guseva, O.; Opitz, A.K.B.; Broadhurst, J.L.; Harrison, S.T.L.; Bradshaw, D.J.; Becker, M. Fe-Sulfide Liberation and Association as a Proxy for the Interpretation of Acid Rock Drainage (ARD) Test Results. In Mine Water-Risk to Opportunity; Wolkersdorfer, C.H., Sartz, L., Weber, A., Burgess, J., Tremblay, G., Eds.; Tshwane University of Technology: Pretoria, South Africa, 2018 ; pp. 345-351.

15. Wolkersdorfer, C.; Nordstrom, D.K.; Beckie, R.D.; Cicerone, D.S.; Elliot, T.; Edraki, M.; Valente, T.; França, S.C.A.; Kumar, P.; Oyarzún, R. Guidance for the Integrated Use of Hydrological, Geochemical, and Isotopic Tools in Mining Operations. Mine Water Environ. 2020, 39, 204-228. [CrossRef]

16. Tabelin, B.C.; Corpuz, R.D.; Igarashi, T.; Villacorte-Tabelin, M.; Alorro, R.D.; Yoo, K.; Raval, S.; Ito, M.; Hiroyoshi, N. Acid mine drainage formation and arsenic mobility under strongly acidic conditions: Importance of soluble phases, iron oxyhydroxides/oxides and nature of oxidation layer on pyrite. J. Hazard. Mater. 2020, 399, 122844. [CrossRef] [PubMed]

17. Tomiyama, S.; Igarashi, T.; Tabelin, C.B.; Tangviroon, P.; Li, H. Acid mine drainage sources and hydrogeochemistry at the Yatani mine, Yamagata, Japan: A geochemical and isotopic study. J. Contam. Hydrol. 2019, 225, 103502. [CrossRef] [PubMed]

18. Tomiyama, S.; Igarashi, T.; Tabelin, C.B.; Tangviroon, P.; Ii, H. Modeling of the groundwater flow system in excavated areas of an abandoned mine. J. Contam. Hydrol. 2020, 230, 103617. [CrossRef]

19. Lapakko, K.A.; Engstrom, J.N.; Antonson, D.A. Effects of particle size on drainage quality from three lithologies. In Proceedings of the 7th International Conference on Acid Rock Drainage (ICARD), St. Louis, MO, USA, 26-30 March 2006; pp. 1026-1050.

20. Eary, L.; Williamson, M. Simulations of the neutralizing capacity of silicate rocks in acid mine drainage environments. J. Am. Soc. Min. Reclam. 2006, 2, 564-577. [CrossRef]

21. Blowes, D.W.; Ptacek, C.J.; Jurjovec, J. Mill tailings: Hydrogeology and geochemistry. In Environmental Aspects of Mine Wastes; Jambor, J.L., Ritchie, A.I.M., Eds.; Mineral Association of Canada, Short Course: Québec, QC, Canada, 2003; Volume 31, pp. 95-116.

22. Ritcey, G.M. Tailings Management in Gold Plants. Hydrometallurgy 2005, 78, 3-20. [CrossRef]

23. Tabelin, C.B.; Igarashi, T.; Villacorte-Tabelin, M.; Park, I.; Opiso, E.M.; Ito, M.; Hiroyoshi, N. Arsenic, selenium, boron, lead, cadmium, copper, and zinc in naturally contaminated rocks: A review of their sources, modes of enrichment, mechanisms of release, and mitigation strategies. Sci. Total Environ. 2018, 645, 1522-1553. [CrossRef]

24. Moodley, I.; Sheridan, C.M.; Kappelmeyer, U.; Akcil, A. Environmentally sustainable acid mine drainage remediation: Research developments with a focus on waste/by-products. Miner. Eng. 2018, 126, 207-220. [CrossRef]

25. Dutta, M.; Islam, N.; Rabha, S.; Narzary, B.; Bordoloi, M.; Saikia, D.; Silva, L.F.O.; Saikia, B.K. Acid mine drainage in an Indian high-sulfur coal mining area: Cytotoxicity assay and remediation study. J. Hazard. Mater. 2020, 389, 304-389. [CrossRef]

26. Igarashi, T.; Herrera, P.S.; Uchiyama, H.; Miyamae, H.; Iyatomi, N.; Hashimoto, K.; Tabelin, C.B. The two-step neutralization ferrite-formation process for sustainable acid mine drainage treatment: Removal of copper, zinc and arsenic, and the influence of coexisting ions on ferritization. Sci. Total Environ. 2020, 715, 136877. [CrossRef]

27. Nengovhela, A.C.; Yibas, B.; Ogola, J.S. Characterisation of gold tailings dams of the Witwatersrand Basin with reference to their acid mine drainage potential Johannesburg, South Africa. Water 2006, 32, 4-8. [CrossRef]

28. Valente, T.; Antunes, M.; Sequeira, B.M.A.; Prudêncio, M.I.; Marques, R.; Pamplona, J. Mineralogical attenuation for metallic remediation in a passive system for mine water treatment. Environ. Earth Sci. 2012, 66, 39-54. [CrossRef] 
29. Valente, T.; Grande, J.A.; De La Torre, M.L. Extracting value resources from acid mine drainages and mine wastes in the Iberian Pyrite Belt. In Proceedings of the International Mine Water Association Symposium 2016-Mining Meets Water-Conflicts and Solutions, Leipzig, Germany, 11-15 July 2016; pp. 1339-1340.

30. Foli, G.; Gawu, S.K.Y. Modifed acid-base accounting model validation and $\mathrm{pH}$ buffer trend characterization in mine drainage at the AngloGold-Ashanti Obuasi mine in Ghana, West Africa. Environ. Earth Sci. 2017, 76, 663-682. [CrossRef]

31. Becker, M.; Charikinya, E.; Ntlhabane, S.; Voigt, M.; Broadhurst, J.; Harrison, S.T.L.; Bradshaw, D. An Integrated Mineralogy-based Modelling Framework for the Simultaneous Assessment of Plant Operational Parameters with Acid Rock Drainage Potential of Tailings. In Mine Water—Risk to Opportunity; Wolkersdorfer, C.H., Sartz, L., Weber, A., Burgess, J., Tremblay, G., Eds.; Tshwane University of Technology: Pretoria, South Africa, 2018; Volume 1, pp. 309-315.

32. Borba, R.P.; Figueiredo, B.R.; Rawlins, B. Geochemical distribution of arsenic in waters, sediments and weathered gold mineralized rocks from Iron Quadrangle, Brazil. Environ. Geol. 2003, 44, 39-52. [CrossRef]

33. Tabelin, C.B.; Hashimoto, A.; Igarashi, T.; Yoneda, T. Leaching of boron, arsenic and selenium from sedimentary rocks: I. Effects of contact time, mixing speed and liquid-to-solid ratio. Sci. Total Environ. 2014, 472, 620-629. [CrossRef] [PubMed]

34. Tabelin, C.B.; Sasaki, R.; Igarashi, T.; Park, I.; Tamoto, S.; Arima, T.; Ito, M.; Hiroyoshi, N. Simultaneous leaching of arsenite, arsenate, selenite and selenate, and their migration in tunnel-excavated sedimentary rocks: I. Column experiments under intermittent and unsaturated flow. Chemosphere 2017, 186, 558-569. [CrossRef] [PubMed]

35. Tamoto, S.; Tabelin, C.B.; Igarashi, T.; Ito, M.; Hiroyoshi, N. Short and long term release mechanisms of arsenic, selenium and boron from a tunnel-excavated sedimentary rock under in situ conditions. J. Contam. Hydrol. 2015, 175-176, 60-71. [CrossRef]

36. Porto, C.G. A Mineralização Aurífera do Depósito Córrego do Sítio e Sua Relação Com o Enxame de Diques Metamáficos No Corpo CACHORRO BRAVO-Quadrilátero Ferrífero-Minas Gerais. Master's Thesis, Universidade Federal de Minas Gerais, Belo Horizonte, Spain, 2008; pp. 1-117. (In English).

37. Goldfarb, R.J.; Groves, D.; Gardoll, S. Orogenic gold and geologic time: A global synthesis. Ore Geol. Rev. 2001, 18, 1-75. [CrossRef]

38. Lobato, L.M.; Ribeiro-Rodrigues, L.C.; Vieira, F.W.R. Brazil's premier gold province. Part II: Geology and genesis of gold deposits in the Archean Rio das Velhas greenstone belt, Quadrilátero Ferrífero. Miner. Depos. 2001, 36, 249-277. [CrossRef]

39. IBRAM-Instituto Brasileiro de Mineração. Available online: http:/ / www.ibram.org.br/ (accessed on 20 September 2020).

40. Deschamps, E.; Ciminelli, V.S.T.; Lange, F.T. Soil and sediment geochemistry of the iron quadrangle, Brazil the case of arsenic. J. Soils Sediments 2002, 2, 216-222. [CrossRef]

41. Vieira, F.W.R.; Biasi, E.E.; Lisboa, L.H. Geology of and excursion to the Morro Velho and Cuiabá mines. In Field and Mine Trip to Quadrilátero Ferrifero. Brazil Gold'91 Internat Symp on the Geology of Gold; Fleischer, R., Grossi, S.J.H., Fuzuikawa, K., Ladeira, E.A., Eds.; Departamento Nacional de Produção Mineral (DNPM): Minas Gerais, Brazil, 1991; pp. 87-99.

42. Vitorino, A.L.A.; e Silva, R.C.F.; Lobato, L.M. Shear-zone-related gold mineralization in quartz-carbonate veins from metamafic rocks of the BIF-hosted world-class Cuiabá deposit, Rio das Velhas greenstone belt, Quadrilátero Ferrífero, Brazil: Vein classification and structural control. Ore Geol. Rev. 2020, 127, 103-789. [CrossRef]

43. Almeida, F.F.M. Origem e Evolução da Plataforma Brasileira; Departamento Nacional de Produção Mineral (DNPM): Rio de Janeiro, Brazil, 1967; pp. 1-36.

44. Alkmin, F.F.; Marshak, S. Transamazonian Orogeny in the Souther São Francisco Craton Region, Minas Gerais, Brazil: Evidence for Paleoproterozoic Collision and Collapse in the Quadrilátero Ferrífero. Precambrian Res. 1998, 90, 29-58. [CrossRef]

45. IBGE-Instituto Brasileiro de Geografia e Estatística. Available online: https:/ / www.ibge.gov.br/ (accessed on 30 September 2019).

46. Moura, W. Especiação de Cianeto para Redução do Consumo no Circuito de Lixiviação de Calcinado da Usina do Queiróz. Dissertação de Mestrado, Departamento de Engenharia Metalúrgica c de Minas-UFMG, Belo Horizonte, Brazil, 2005; pp. 1-138. (In English).

47. ANM-Agencia Nacional de Mineração. Available online: https://www.gov.br/anm/pt-br (accessed on 30 September 2019).

48. Ciminelli, V.S.T. Arsenic in mining: Sources and stability. In One Century of the Discovery of Arsenicosis in Latin America (1914-2014), Proceedings of the 5th International Congress on Arsenic in the Environment, Buenos Aires, Argentina, 2014; Taylor \& Francis Group: London, UK, 2014; pp. 3-7.

49. USEPA-United States Environmental Protection Agency. Test Methods for Evaluating Solid Waste—Physical/Chemical Methods (SW-846); USEPA: Washington, DC, USA, 1996.

50. MEND-The Mine Environment Neutral Drainage Program. Coastech Research, Acid Rock Drainage Prediction Manual, MEND Project Report; MEND: Ottawa, ON, Canada, 1991.

51. MEND-The Mine Environment Neutral Drainage Program. Prediction Manual for Drainage Chemistry from Sulphidic Geologic Materials. MEND Report. 1.20.1; MEND: Ottawa, ON, Canada, 2009.

52. USEPA-United States Environmental Protection Agency. Acid Mine Drainage Prediction: Technical Document, US EPA, Office of Solid Waste Special Waste Branch, EPA530-R94-036, NTIS PB94-201829; USEPA: Washington, DC, USA, 2018.

53. Oliveira, W.S.; Neves, M.F.; Brito, M.M.B.; Mesquita, R.M.M.; Costa, D.S. Uso da flotação para o aproveitamento de um rejeito fino de minério de ouro. In Proceedings of the XXVI Encontro Nacional de Tratamento de Minérios e Metalurgia Extrativa 2015, Poços de Caldas-MG, Brasil, 18-22 October 2015. 
54. CONAMA (CONSELHO NACIONAL DE MEIO AMBIENTE). Resolução nº 396, de 03 de abril de 2008. Dispõe Sobre a Classificação e Diretrizes Ambientais Para o Enquadramento das Águas Subterrâneas e dá Outras Providências; CONAMA: Brasília, Brazil, 2008.

55. Erguler, G.K.; Erguler, Z.A.; Akcakoca, H.; Ucar, A. The effect of column dimensions and particle size on the results of kinetic column test used for acid mine drainage (AMD) prediction. Miner. Eng. 2014, 55, 18-29. [CrossRef]

56. Falagán, C.; Grail, B.M.; Johnson, D.B. New approaches for extracting and recovering metals from mine tailings. Miner. Eng. 2016, 106, 71-78. [CrossRef]

57. Li, H.; Ma, A.; Srinivasakannan, C.; Zhang, L.; Li, S.; Yin, S. Investigation on the recovery of gold and silver from cyanide tailings using chlorination roasting process. J. Alloy. Comp. 2018, 763, 241-249. [CrossRef]

58. Lu, H.; Qi, C.; Li, C.; Gan, D.; Du, Y.; Li, S. A light barricade for tailings recycling as cemented paste backfill. J. Clean. Prod. 2020, 247, 119388. [CrossRef]

59. Araya, N.; Kraslawski, A.; Cisternas, L.A. Towards mine tailings valorization: Recovery of critical materials from Chilean mine tailings. J. Clean. Prod. 2020, 263, 121555. [CrossRef]

60. Alcalde, J.; Kelm, U.; Vergara, D. Historical assessment of metal recovery potential from old mine tailings: A study case for porphyry copper tailings, Chile. Miner Eng. 2018, 127, 334-338. [CrossRef]

61. Girotto, L.; Espíndola, E.L.G.; Gebara, R.C.; Freitas, J.S. Acute and Chronic Effects on Tadpoles (Lithobates catesbeianus) Exposed to Mining Tailings from the Dam Rupture in Mariana, MG (Brazil). Water Air Soil Pollut. 2020, 231, 1-15. [CrossRef]

62. Aires, U.R.V.; Santos, B.S.M.; Coelho, C.D.; Silva, D.D.; Calijuri, M.L. Changes in land use and land cover as a result of the failure of a mining tailings dam in Mariana, MG, Brazil. Land Use Policy 2018, 70, 63-70. [CrossRef]

63. Thompson, F.; Oliveira, B.C.; Cordeiro, M.C.; Masi, B.P.; Rangel, T.P.; Paz, P.; Freitas, T.; Lopes, G.; Silva, B.S.; Cabral, A.S.; et al. Severe impacts of the Brumadinho dam failure (Minas Gerais, Brazil) on the water quality of the Paraopeba River. Sci. Total Environ. 2020, 705, 135914. [CrossRef] [PubMed]

64. Rotta, L.H.S.; Alcântara, E.; Park, E.; Negri, R.G.; Lin, Y.N.; Bernardo, N.; Mendes, T.S.G.; Filho, C.R.S. The 2019 Brumadinho tailings dam collapse: Possible cause and impacts of the worst human and environmental disaster in Brazil. Int. J. Appl. Earth Obs. Geoinf. 2020, 90, 102119. [CrossRef] 